\title{
THE CULTUROLOGICAL ASPECTS OF FLASH FICTION BY ERNST WIECHERT
}

Summary. The article attempts to analyze the culturological aspects of Ernst Wiechert's flash fiction, which emphasizes the topical aspects of the socio-political situation of the 20-30s of the twentieth century in Germany under conditions of internal emigration. In addition, attention is focused on the issue of genre definitions of short stories and novels, the specifics of interpretation and interpretation of the genre of short stories in German literary criticism are revealed. A defining feature of E. Wiechert's short stories and novels is anthropocentrism. Touching on anthropological problems, the author solves them at the household level. Through the prism of allegory, the author emphasizes the actual reality with the transition to Eternity. Distinguishing between short stories and novels, which are the main ones in E. Wiechert's flash fiction of the 1920's and 1930's, it is necessary to single out their ontological basis.

The author adheres to the principles of cyclical prose works. In this case, the genre of short stories is often transformed into a story that reflects his worldview concept. The cycles of E. Wiechert's novels are also characterized by the author's idea of the composition, the independence of the works united in the cycle and the centripetal nature of the composition. The peculiarity of the cycles of the German writer lies in their clear structure, the subordination of all elements to the general idea.

It can be concluded that in the 1920's and 1930's cyclicity became the defining principle of E. Wiechert's work. This is a cycle at the level of formation of the author's art world. Analyzing the problem of the cycle in the work of E. Wiechert, it is advisable to pay attention not only to literary but also culturological aspects. In this context, we are talking about the ontological status of both the genres that make up the work of art and the cycle itself. All this gives grounds to assert that the flash fiction of E. Wiechert 20-30's of the twentieth century is a subject to the understanding of existential issues.

Key words: flash fiction, novel, short story, inner emigration, cyclical, anthropocentrism, interpretation.

Formulation of the problem. Ernst Wiechert's multi-genre creative work (1885-1950) played a significant role in the development of the German-language literary process of the first half of the twentieth century. He is the author of novels, among which the wide prose canvas "Dead Forest" ("Totenwald", 1939) [1], as well as cycles of poems and journalistic articles have gained considerable resonance. E. Wichert's reflections on the topical aspects of the socio-political situation of that time under conditions of internal emigration were published in two autobiographical books: "Forests and People. Youth" ("Wälder und Menschen. Eine Jugend", 1936), "Years and times. Memories" ("Jahre und Zeiten. Erinnerungen", 1949). In the early 1930s, the artist created a series of plays for the theater. In turn, during the 20-30's of the twentieth century. E. Wichert paid considerable attention to the forms of small genres: short stories and novels. "The term "flash fiction" ("Kurzprosa") includes short stories, miniatures, aphorisms, diary entries, letters, unfinished fragments, strokes and even conversations. Each of these genre definitions, as we know, has no complete boundaries" [2; 5], such a definition is given by the Russian literary critic V. Zusman. In this regard, German literary criticism, the genre composition of flash fiction differs from the interpretation given in the proposed definition. This is primarily due to the peculiarities of the development of literary criticism in Germany, as well as the cultural and historical identity of the country. Thus, the genres of flash fiction include "novel" ("Novelle"), "story" ("Erzählung", "Geschichte"), "story", "short story" ("Kurzgeschichte"), "concentrated story" ("Kürzestgeschichte"), "Calendar history" ("Kalendergeschichte"), "prose miniature" ("Prosaminiatur"), "essay" ("Skizze"), "poetry in prose" ("Prosagedicht"), "feuilleton"("Feuilleton"), "Anecdote" [3, p. 20].

All this emphasizes the relevance of the study of the peculiarities of the flash fiction by E. Wiechert.

Research analysis. The works of such researchers as M. Bakhtin, F. Wallman, L. Ginzburg, M. Hirschman, I. Denisyuk, K. Doderer, B. Eichenbaum, I. Zymomrya, L. Kaufman, I. Klein, N. Leites, F. Lokeman, Yu.M. Lotman, T. Meiserska, J. Mueller, G. Pospelov, K. Rothman, B. Tomaszewski, M. Fick, K. Fischer, O. Freidenberg and others are devoted to the question of classification and systematization of genres of flash fiction. In this regard, it should be noted that in Ukrainian literary studies E. Wiechert's artistic models have not been systematically studied. The works of the German writer have not been translated into Russian or Ukrainian languages.

Among the critical investigations about the life and work of E. Wiechert we should mention such works as "Theme of anti-fascism in the work of E. Wiechert (Before the evolution of the creative method)" (1979) L. Kaufmann, "The work of anti-fascist writers in Germany during Nazism. Problems. Poetics" (1983) L. Kaufmann, "The study of the creative work of Ernst Wiechert" ("Untersuchungen zum Werk Ernst Wiecherts") (1987) A. Messing, "Ernst Wiechert's dissident novel "The White Buffalo or the Great Justice" ("Der weisse Büffel oder grossen Gerechtigkeit") (1989) F. Parkes-Perret, "Education for barbed wire. The Significance and Dilemma of Ernst Wiechert's Conservative Opposition» («Erziehung hinter Stacheldraht. Wert und Dilemma von Ernst Wiecherts konservativer Opposition") (1999) L. Krenzlin, "Ernst Wiechert. The One Who Moves Hearts" ("Ernst Wiechert. Der die Herzen bewegt") (2003) X.-M. Plesske, "The Concept of Human in Ernst Wiechert's flash fiction of the 1920s and 1930s" (2004) O. Lukinova.

The purpose of the article is to reveal the features of the genre structure of Ernst Wiehert's flash fiction of the 20s and 30s of the 20th century within in the German literature emigration context. 
The main material presentation. Systematic study of German-language literature of the twentieth century under modern conditions requires clarification of the established scientific schemes of coverage of its history. This applies, in particular, to the role of literature in exile, which has long been a secondary object of historical and literary research. Taking into account the creative achievements of authors who lived and worked in exile, including domestic, makes it possible to build an integrated picture of the artistic achievements of the German-speaking cultural space.

E. Wiechert's flash fiction of the 1920s and 1930s generally does not differ in genre diversity. To some extent, this is because it covers the stories and short stories that the author has combined into cycles. In this context, it deserves an in-depth study of the genre definitions of short stories and narratives, and hence - the disclosure of the specifics of interpretation and interpretation, especially the genre of short stories in German literary criticism. It is noteworthy that the definition of these genres is often perceived by one or another author conditionally. Thus, E. Wiechert's appeal to a particular genre is determined not only by the peculiarities of his artistic method associated with the author's worldview, but also by the neo-romantic issues to which he appeals in his work.

At the turn of the XIX-XX centuries. The novel became one of the most popular genres in Germany. The well-known theorist of German literature G. Fischer argues: at the beginning of XX century. It became "difficult and almost impossible to define genres, because each new work of a genre can completely erase the ideas that have already formed about it". The researcher rightly believes that "the main elements of a flash fiction can be named, but there will always be flash fictions that do not have some of its components" [4, p. 172-173].

German novel of the XX century differs from other forms not only in size but also in the tone of events. An unexpected event determines the whole subsequent development of the plot and the characters are directly related to it. A prerequisite for the novel should also be "spontaneity, lack of smooth development of events" $[4$, p. 173]. Beginning with the work of K.M. Wiland, the novel is defined as a special form of flash fiction. First of all, the epic beginning is important. Instead, the author's appeal to the recipient is pushed to the background. Romantics bring to the genre of flash fiction fantastic, symbolic elements, dream motifs. Realists focus on posing serious problems that are necessarily related to human life. Ludwig Tick gives the novel a new element, a sharp, unexpected turn of events. The so-called "falcon" theory distinguishes between a story and a short story on the basis of "an unexpected turn of events to something new" [5]. In this regard, K. Doderer cites the words of J.W. Goethe, who called the main element of the novel "an unheard of event" ("unerhörte Begebenheit") [6, 63].

To reveal the purpose of this exploration, it is advisable to clarify the possible grounds for comparing the novel with other forms of small genres ("Kurzgeschichte", "Erzählung"). Mr. Fischer suggested the following comparison: "A short story cannot be abstract, its plot is necessarily related to social issues. It must have an addressee and its own morals" [4, p. 172]. "The novella", emphasizes the scientist, "loves the ordinary, the everyday, but at the same time the unexpected, the fateful" [4, p. 173]. The novel should have a frame. Then Theodore Storm called the novella - given its framework composition - "the sister of drama" [4, p. 173]. If it is not there, it is a chronological story (narrative) [4, p. 173]. According to K. Figner, a story is a "short form of a story where there is a plot that is built on the comparison of time". I. Klein, in turn, defines the story as a "natural movement of events" [7, p. 221]. The concentration of the event described in the novel was especially noted by art theorist Friedrich Theodor Fischer. In 1857, in the studio "Aesthetics", he emphasized: "The novel refers to the novel as a ray of sunshine to the light mass" [5, p. 154].

Klaus Doderer, an authoritative German researcher of the theory of "short story" ("Kurzgeschichte"), distinguishes, in fact, a short story and a novel: great depicted event" [6, p. 63]. K. Doderer also emphasizes the following points: "In the novel the depicted event is motivated by the course of the events themselves, in the short story - it is not. The novel shows the development of events, the short story - is not" [6, p. 64].

In our opinion, the main components of the novel's genre are most comprehensively defined in the thorough edition of German History of Literature in 12 Volumes (1994): the size between the novel and the Kurzgeschichte; a plot taken from life or close to reality; the presence of an event, an unexpected, unexpected turn of events that would change the life or perception of the world of the protagonist; single-plot, straightforward composition; objective, uncommented manner of presentation; condensed, free from pathos and verbal ornaments style; the presence of a symbol [5, p. 157] and, finally, a special function of the narrator. G. Fischer speaks in this context about the "objective presentation and neutrality of the narrator" [4, p. 173].

Thus, answering the question of whether the principle of differentiation of the genres of short stories and novels is fundamental for E. Wichert, we can say: the boundaries between these forms are rather conditional. Often E. Wichert's short stories should be defined at the level of the story. An example here is the short story "Farm of the Dead" ("La Ferme morte", 1933). A number of his short stories (for example, "Simple Death" ("Der einfache Tod", 1931-1936), "Legend of the Last Forest" ("Die Legende vom letzten Wald", 1923-1924)) do not have a framework composition and an unexpected change of events. Hence their closeness to the short story, which indicates that for E. Wiechert it is not the structural formal properties of genres that are important, but their essential qualities.

A remarkable detail: for E. Wiechert, short stories and novels are not endowed with genre stability. Thus, following the romantics, the writer introduces into the novel symbolic elements that often become leitmotifs. E. Wiehert uses the images of the forest as a symbol of life, the bridge as a symbol of the transition between real and unreal worlds ("Der Kinderkreuzzug" ("Children's Crusade"), 1926; "Die Flucht ins Ewige" ("Escape to Eternity"), 1927; "Der silberne Wagen" ("Silver Trolley"), 1928; "Hirtennovelle" ("Shepherd's Novel"), 1934). Most short stories have a "classic" structural element - an "unheard of event". In addition, this genre form contributes to the greatest concentration of content and makes it possible to reflect the full range of worldviews of the author. It is in stories and novels that $\mathrm{E}$. Wiechert develops the main themes and motives of his work.

The defining feature of E. Wiechert's short stories and novels is anthropocentrism. Touching on anthropological problems, the author solves them at the household level. And, despite the allegorical component, he emphasizes the actual reality with the transition to Eternity. Distinguishing between short stories and novels, which are the main ones in E. Wiechert's flash fiction of the 20s and 30s, it is necessary to single out their ontological basis [1, p. 87].

E. Wiechert's prose of the 1920 's and 1930 's is generally cyclical. It enabled the author to activate the genre potential related 
to the understanding of ontological problems. At the same time, it manifests the process of blurring genre boundaries. According to L. Lyapina, the separation of the cycle from the whole paradigm of multicomponent units is due to its integrity as a result of the interaction of a number of components: "The cycle is an aesthetic whole, which is a series of independent works. All of them belong to one kind of art, created by one author and composed by him in a specific sequence" $[8, p$. 3]. During the period under study, E. Wiechert created three cycles of novels: "Silver cart. Seven novels" ("Der silberne Wagen. Sieben Novellen", 1928), "Flute of the Pan" ("Die Flöte des Pan", 1930), "Holy Year. Five novels" ("Das heilige Jahr. Fünf Novellen", 1936).

E. Wiechert adheres to the principles of cyclical prose works, despite the fact that the genre of novel in him is often transformed into a story. They reflect his worldview. As I. Kutlemina notes, "the cycle is a kind of artistic integrity, the desire for detailed elaboration of the stated theme, testifies to the concept of the world, which can be represented as a mosaic panel, where each element is equally important and significant" [9, p. 6]. It can be argued that in the 1920's and 1930's cyclicity became the defining principle of E. Wiechert's work. This is a cycle at the level of formation of the author's art world. On the other hand, cyclicity can be considered as a "trend that characterizes not only the poetics of a particular work, but also the artistic thinking of the author, a group of contemporary authors, the literary era" $[9$, p. 6].

As M. Darwin, L. Lyapina, I. Fomenko emphasize, the prose cycle is less studied in the theoretical aspect than the lyrical [10; $8 ; 12]$. Researchers note the general conditions of its existence: the author's context, the unity of works, which is due to the intention of the creator, the general name of the cycle, a relatively stable composition in several publications. The author's conditional representation of the cycle is decisive (V. Sapogov, I. Fomenko, L. Lyapina, Y. Shatin) $[9$, p. 6]. The selection of short stories that form cycles in E. Wiechert is not accidental. After all, short stories combined into cycles have the logic of internal construction. Each of the three cycles begins with a preface by the author, which serves as a not thematic, but always semantic "connection" of works into a single whole. The cycles of E. Wichert's novels are also characterized by the author's idea of the composition, the independence of the works united in the cycle and the centripetal nature of the composition. The peculiarity of the cycles of the German writer lies in their clear structure, the subordination of all elements to the general idea.

Cyclo-forming bonds play an extremely important role in the author's cycle. There are three main types among them: title, general prototypes of the composition and vocabulary (I. Fomenko) $[9$, p. 8]. The title is one of the main components of the organization of the text in E. Wiechert. He is self-sufficient. Two main aspects are important for understanding the title as a phenomenon: a) the identity of the title with the non-textual series (everyday realities, cultural and historical stratum, etc.), in other words, its associative, non-textual motivation; b) the title / text ratio (direct, intratextual motivation). The role of the header in the loop is also determined by its subordination to the whole, the connection with other headings of the loop. For example, E. Wiechert duplicates the title of the series "Der silberne Wagen" with the title of a separate novel. I. Kutlemina rightly notes that such a technique is "an extremely important way of organizing an epic ensemble, which was discovered in the early 19th century in the lyrical cycle - a prototype of supporting elements that reveal the semantically filled role of the title in the cycle of works" $[9$, p. 8].
The titles of the cycles can be divided into three main groups $[9,8]$ : the nomination with zero connotation ("Veronika" ("Veronika", 1931-1936); titles with implicit authorial attitude ("Not beautiful" ("Die Häßliche", 1930)), "Simple Death" ("Der einfache Tod", 1931-1936), "Candidate for Suicide" ("Todeskandidat", 1933), the semantic content of the headlines, which relates to the historical paradigms of world art [9, p. 9] ("Der Hauptmann von Kapernaum", 1928-1929), "The Seventh Day ("Der siebente Tag", 1928), "Advent of the Dead" ("Advent der Toten", 1931), "The Apostle" ("Der Jünger"). It is noteworthy that E. Wiechert uses the least connotations with zero connotations, instead he pays attention to intertextual, precedent titles. The titles of novels in cycles serve not so much as an announcement of the theme, stylistic organization, but as a concentration of the author's concept.

Conclusions. Analyzing the problem of the cycle in the work of $\mathrm{E}$. Wiechert, it is advisable to pay attention not only to literary but also culturological aspects. In this context, we are talking about the ontological status of both the genres that make up the work of art and the cycle itself. All this gives grounds to assert: the flash fiction of E. Wiechert of 20-30-ies of the twentieth century is a subject to the understanding of existential issues.

\section{References:}

1. Rosłan J. Ernst Wiechert : życie i dzieło. Olsztyn : Ośrodek Badań Naukowych im. Wojciecha Ketrzyńskiego,1992. 159 s.

2. Зусман В.Г. Художественный мир Франца Кафки: малая проза. Нижний Новгород : Изд-во ННГУ, 1996. 182 с.

3. Зимомря І. Австрійська мала проза XX століття: художня світобудова. Дрогобич-Тернопіль : Посвіт, 2011. 396 с.

4. Fischer H. Studien zur deutschen Märendichtung. Tübingen Niemeyer, 1983. $556 \mathrm{~S}$.

5. Deutsche Literaturgeschichte. Von den Anfängen bis zur Gegenwart. Fünfte, überarbeitete Auflage / [von Wolfgang Beutin, Klaus Ehlert, Wolfgang Emmerich, Helmut Hoffacker, Bernd Lutz, Volker Meid, Ralf Schnell, Peter Stein, Inge Stephan]. Stuttgart-Weimar : J.B. Metzler Verlag, 1994. $630 \mathrm{~S}$.

6. Doderer K. Die Kurzgeschichte in Deutschland. Ihre Form und ihre Entwicklung. Darmstadt : Wissenschaftliche Buchgesellschaft, 1969. $103 \mathrm{~S}$.

7. Klein J. Geschichte der deutschen Novelle von Goethe bis zur Gegenwart. Wiesbaden: Steiner, 1960.674 S.

8. Ляпина Л.Е. Циклизация в русской литературе : автореф. дис. ... док. филол. наук. Санкт-Петербург, 1995. 38 с.

9. Кутлемина И.В. Поэтика малой прозы Л.С. Петрушевской : автореф. дисс. ... канд. филол. наук. Северодвинск, 2002. 20 c.

10. Дарвин М.Н. Проблема цикла в изучении лирики. Кемерово : КГУ, 1983. $104 \mathrm{c}$

11. Кауфман Л.С. Человек и время в творчестве Э. Вихерта 20-30-х годов. Образ героя - образ времени. Межвузовский сборник науч. трудов. Воронеж : Изд-во Воронежского университета, 1984. $136 \mathrm{c}$

12. Фоменко И.В. Поэтика лирического цикла : автореф. дис. ... докт. фил. наук. Москва, 1990. 31 с.

\section{Жовтані Р. Я. Культурологічні аспекти малої прози Ернста Віхерта}

Анотація. Системне вивчення німецькомовного письменства XX ст. за сучасних умов вимагає уточнень щодо сформованих наукових схем висвітлення його історії. Це стосується й ролі літератури у вигнанні, яка тривалий час залишалася другорядним об'єктом історико-літературних досліджень. Урахування творчих здобутків авторів, які 
жили й творили в еміграції, зокрема й внутрішній, дає можливість вибудувати інтегральну картину мистецьких досягнень німецькомовного культурного простору.

У статті зроблено спробу проаналізувати культурологічні аспекти малої прози Ернста Віхерта, яка увиразнює злободенні аспекти суспільно-політичної ситуації 20-30-х pp. XX ст. у Німеччині за умов внутрішньої еміграції. Крім того, акцентовано увагу на питанні жанрових дефініцій новели та оповідання, розкрито специфіку тлумачення й трактування жанру новели у німецькому літературознавстві. Визначальна особливість новел та оповідань Е. Віхерта - антропоцентризм. Торкаючись антропологічних проблем, автор вирішує їх на побутовому рівні. Крізь призму алегорії автор виакцентовує актуальну реальність із переходом у Вічність. Розмежовуючи оповідання та новелу, які є основними в малій прозі Е. Віхерта 20-30-х рр., варто виокремити їх онтологічну основу.

Автор дотримується принципів циклічності прозових творів. При цьому жанр новели нерідко трансформується в оповідання, яке відображає його світоглядну концепцію. Циклам новел Е. Віхерта притаманні: авторський задум композиції, самостійність творів, об'єднаних у цикл, та доцентровість композиції. Особливість циклів німецького письменника полягає в чіткій структурованості, підпорядкуванні всіх елементів загальному задуму.

Можна стверджувати, що у 20-30-х рр. циклічність постає визначальним принципом творчості Е. Віхерта. Тут ідеться про циклічність на рівні формування авторського художнього світу. Аналізуючи проблему циклу у творчості Е. Віхерта, доцільно звертати увагу не тільки на літературні, але й на культурологічні аспекти. У цьому контексті йдеться про онтологічний статус як жанрів, які складають художнє творіння, так і самого циклу. Усе це дає підстави стверджувати, що мала проза Е. Віхерта 20-30-х рр. ХХ ст. підпорядкована осмисленню буттєвих питань.

Ключові слова: жанр, мала проза, новела, оповідання, внутрішня еміграція, циклічність, антропоцентризм, інтерпретація, концепт, поетика. 